\title{
Hamlet 3
}

LAWRENCE RHU

On $42^{\text {nd }}$ Street, beyond the bright marquee, alight with Hamlet 2,

We find its star, Steve Coogan. He plays Dana Marschz,

Who came from Canada to Tucson, my hometown, or so it seems

At least as much as Hamlet seems a myth of origins

Enabling our imaginations to conceive of selfhood

In terms of consciousness as process, self-awareness

Struggling to proceed, man or woman thinking,

The American scholar in Wittenberg or Elsinor, Concord or TucsonWherever that might be or we might find ourselves.

Skull in hand, Hamlet stops to think, and thinks iconically,

"Am I the cause of what I cause, the subject of what happens to me?"

Essays, soliloquies, and cogitos put us in our place in time,

With mysteries and problems to abide or solve

Or, bit by bit, address somehow.

When I think of starting out, I think of Tucson:

The Old Pueblo, La Fiesta de los Vaqueros,

The Ash Alley Singers with Linda Ronstadt,

The Indians' spring training at Hi Corbett Field

Nearby the public links. Once, on the first tee, Hoyt Wilhelm

The famous knuckleballer joined Grandfather Ford and me.

We played the front nine as a threesome.

Hamlet then was beyond my ken. 
From the championship tees, of course, the course plays differently, And distances in time will change, paradigms will shift.

When Camden, South Carolina's own Larry Doby was playing centerfield For Cleveland, Grandfather Ford took me to a church event To meet Jackie Robinson, who shook my hand with his much larger hand.

Born in Dundee, oldest of six, reared mainly by his motherA milliner who always wore a bit of ruching at the neck And entered by the servants' doorGrandfather skipped high school to help support the family. When he worked at Pittsburgh's Stock Exchange, He'd leave at 3 for Forbes Field during baseball season. He shagged balls there and posted hits and runs On the scoreboard in leftfield. And he had tales to tell Of Honus Wagner, the Flying Dutchman, to a wide-eyed boy. Later, he became a Baptist minister-American, not Southern, He'd interject, as though those two were opposites.

We might call him a self-made man, but isn't that heretical? Grandfather told congregations modest edifying jokes:

The car he drove, which bore his name, was good enough for him. It took him where he wished to go. Often it took us to Oracle, North of Tucson, where he'd pinch-hit for another preacher.

I may have been star-struck, but I started hearing "Wish" and "need" as rivals for whatever I was seeking. Was our journey's end, somehow or not, achieved Step after step along the way? Or, even now, am I, retrospectively, Getting ahead of myself, out front and out of sync?

On $42^{\text {nd }}$ Street, beyond the bright marquee, alight with Hamlet 2, We find Dana Marschz, who came from Canada to Tucson, 
"Where," he says, "dreams go to die." Yet he proved otherwise,

Directing West Mesa High's production all the way

To the Great White Way-and adding Jesus to the monstrous mix.

There, spectacularly, it flops,

So Dana seeks to minimize his students' disappointment,

"No matter where you go, it will always be better than Tucson."

There's no West Mesa High in Tucson, Mesa is near Phoenix, Hamlet 2 was filmed in Albuquerque.

Still I sing with gratitude for prehistorical deeds.

In the myth that heals my mind, they count. Their sum's a figure in some cosmic tally. The practice range and public links at East Broadway And Alvernon define the real estate where I worked hard at play. Grandfather nursed my dreams as though they were his own And dreaming seems enough with such a guide to start From somewhere and to move ahead from there. 